\title{
ON $\varphi$-CONVEX FUNCTIONS
}

\section{Eshaghi Gordji, M. Rostamian Delavar and M. De La Sen}

Abstract. In this paper we introduce the notion of $\varphi$-convex functions as generalization of convex functions. Some basic results under various conditions for the function $\varphi$ are investigated. Moreover, we establish Jensen and Hermite-Hadamard type inequalities related to $\varphi$-convex functions. Also, the notions of $\varphi_{b}$-convex and $\varphi_{E}$-convex functions, which are generalization of $\varphi$-convex functions are introduced and some new results related to these new settings are obtained.

Mathematics subject classification (2010): 26A51, 26D15, 52A01.

Keywords and phrases: $\varphi$-convex function, Jensen inequality, Hermite-Hadamard inequality.

\section{REFERENCES}

[1] K. J. Arrow And A. D. Enthoven, Quasiconcave Programming, Econometrica, 29 (1961) 779 800 .

[2] C. R. Bector and C. Singh, B-vex functions, J. Optimiz. Theory. App. 71 (1991) 237-254.

[3] C. Fulga AND V. PREDA, Nonlinear programming with E-preinvex and local E-preinvex functions, Eur. J. Oper. Res. 192 (2009) 737-743.

[4] M. A. Hanson, On sufficiency of the Kuhn-Tucker conditions, J. Optimiz. Theory. App. 80 (1981) 545-550.

[5] X. F. Li, J. L. Dong AND Q. H. LiU, Lipschitz B-vex functions and nonsmooth programming, J. Optimiz. Theory. App. 3 (1997) 557-573.

[6] O. L. Mangasarian, Pseudo-Convex Functions, SIAM. J. Control. 3 (1965) 281-290.

[7] S. R. Mohan and S. K. Neogy, On invex sets and preinvex functions, J. Math. Anal. Appl. 189 (1995) 901-908.

[8] A. W. Robert And D. E. VARBEG, Convex functions, Academic Press (1973).

[9] Y. R. Syau And E. S. LeE, Some properties of E-convex functions, Appl. Math. Lett. 18 (2005) 1074-1080.

[10] E. A. Youness, E-convex sets, E-convex functions and E-convex programming, J. Optimiz. Theory. App. 102 (1999) 439-450. 